\title{
Journals, Please go Further!
}

\author{
Yue Zhang, Weiyan Wang and Zhiyi Zhang \\ The first Clinical college of Harbin Medical University, China
}

Submission: July10, 2017; Published: July 27, 2017

*Corresponding author: Dr. Yue Zhang, The first Clinical college of Harbin Medical University, 23\# Youzheng Street, Harbin, China; Email: toronto101@163.com

\section{Editorial}

Information overloads and barrages researchers. How are we to face this deluge? Social media may help [1] but this may lead to inaccuracies Smoglia \& Kendall [2]. The situation is worse in China because some Chinese media use "translation problems" as an excuse so that they avoid the risk of blame. Formatting alone Moore [3] is trivial for non-native English readers and writers compared with bilingual editing for high-profile journals in English. In our view, we need journals in English plus the local language (bilingual). Our casual survey hints that some Editors-in-Chief agree that journals could shoulder the burden of providing high-quality bilingual editing. This is feasible if one considers the costs of translation programs and the additional publication fees they may incur. Japan's bilingual journals may have contributed to their harvest of more Nobel laureates than any other Asian nation. We wonder if bilingual research might occasionally provide more inspiration for China and non-English speaking countries as well.

Another publication issue hampers Chinese research. Although joint first authorship (and co-correspondence) have promoted collaboration and expanded research networks. However, most institutes in China only credit publications using

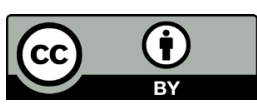

This work is licensed under Creative Commons Attribution 4.0 Licens DOI: 10.19080/GJORM.2017.01.555574 the "first affiliation" rule. If co-corresponding authors are from the same institution, both are credited; however if they are from different institutions, domestic correspondence receives full credit via the "first affiliation" rule. This policy turns some potential collaborators into competitors, weakening motivation for collaboration. Fortunately, many institutions abroad are less enamored of the "first affiliation" rule and international collaboration takes place. Further more, as publication numbers matter, which pressures researchers to write many trivial papers rather than a few good ones, it could be very helpful if the journals indicate which affiliations "contributed equally", especially when multiple institutes are involved. Alongside bilingual publications, this would enhance collaboration within the Chinese community, allowing it to flourish. Maybe this is meaningful for academics in other countries.

\section{References}

1. Landhuis E (2016) Scientific literature: Information overload. Nature 535(7612): 457-458.

2. Smoliga JM, Kendall CJ (2017) Inaccuracies: Axe science hype from social media. Nature 542(7639): 31.

3. Moore JP (2017) Publishing: Journals, do your own formatting. Nature 542(7639): 31.

\section{Your next submission with Juniper Publishers} will reach you the below assets

- Quality Editorial service

- Swift Peer Review

- Reprints availability

- E-prints Service

- Manuscript Podcast for convenient understanding

- Global attainment for your research

- Manuscript accessibility in different formats

( Pdf, E-pub, Full Text, Audio)

- Unceasing customer service

Track the below URL for one-step submission https://juniperpublishers.com/online-submission.php 